\title{
Hyperbilirubinemia with urinary tract infection in infants younger than eight weeks old
}

\begin{abstract}
Background: Urinary tract infection (UTI) is a common clinical problem in febrile infants younger than 8 weeks old, with prevalence between $5 \%$ and $11 \%$. Previous studies have noted that jaundice may be one of the first signs of a bacterial infection in infants.

Aim: is to assess the presence of urinary tract infection in newborns with unexplained, indirect hyperbilirubinemia in the first eight weeks of life.

Patients and methods: This study was conducted on 100 full term and preterm neonates with neonatal jaundice, 64 males and 36 females, and 20 neonates as control group, 10 males and 10 females.

Results: shows that $>90 \%$ of cases with positive urinary culture had prolonged duration of jaundice $>14$ days and the maternal infection was the leading cause of UTI.

Conclusion: Testing for UTI should be a part of the diagnostic evaluation of neonates with prolonged unexplained jaundice. Maternal (obstetric) infections should be properly investigated and treated to prevent UTI in newborns as it was the leading cause of UTI in neonates. Further studies are needed to clarify the effect of hyperbilirubinemia on the bactericidal activity in the sera of jaundiced infants.
\end{abstract}

Keywords: indirect hyperbilirubinemia, urinary tract infections, neonatal jaundice
Volume I Issue 6 - 2014

\author{
Yasser K Rashed,' Ahmad A Khtaband, ${ }^{2}$ \\ Ahmad MAlhalaby ${ }^{2}$ \\ 'Pediatric Hepatology Department, Menoufiya University, Egypt \\ ${ }^{2}$ Pediatrics Department, Menoufiya University, Egypt
}

\begin{abstract}
Correspondence: Yasser K Rashed, Pediatric Hepatology Department, National Liver Institute, Menoufiya University, Shebin ElKom, Menofiya, Egypt, Tel 00971-055-5270886, Email yasserrashed79@yahoo.com
\end{abstract}

Received: September 02, 2014 | Published: September 12 2014
Abbreviations: UTI, urinary tract infection; NLI, national liver institute; CRP, c- reactive protein; SPSS, statistical program for social science; G6PD, glucose-6-phosphate dehydrogenase

\section{Introduction}

Jaundice is a frequently encountered problem during the newborn period. Although up to $60 \%$ of term, and $80 \%$ of preterm newborns have clinical jaundice in the first week of life, few have a significant underlying disease. However, it can be associated with severe illnesses such as hemolytic disease, metabolic and endocrine disorders, enzymatic deficiencies of the liver and infections. ${ }^{1}$ Urinary tract infection (UTI) is a common clinical problem in febrile infants younger than 8 weeks old, with prevalence between $5 \%$ and $11 \%$. Previous studies have noted that jaundice may be one of the first signs of a bacterial infection in infants. ${ }^{2}$

\section{Aim of the study}

The aim of the study is to assess the presence of urinary tract infection in newborns with unexplained, indirect hyperbilirubinemia in the first eight weeks of life, and if there is any relation between them.

\section{Patients and Methods}

This study was conducted on100 full term and preterm neonates with neonatal jaundice, 64 males and 36 females, and 20 neonates as control group (case control study), 10 males and 10 females. They were selected from the NICU in Zagazig University hospital, Mit Ghamr general hospital, El taisier private hospital in Zagazig and National Liver Institute (NLI) hospital- Menofiya University. Exclusion criteria: neonates above8 weeks of age, jaundiced neonates with bilirubin levels $<15 \mathrm{mg} \%$, also Patients with jaundice in the first 24 hours with signs of hemolysis and cases with fever and signs of sepsis.
All cases were subjected to the following, careful history including mode of delivery \& instrument use, Factors that might lead to sepsis \& urinary tract infections as premature rupture of membranes, maternal fever Family history of jaundice in a previous sibling, duration of jaundice, maternal $\mathrm{RH}$ or $\mathrm{ABO}$ for detection of incompatibility, family history of chronic hemolytic anemia presenting in the neonatal period (spherocytosis \& elliptocytosis) and history of G6PD in a family member. Thorough clinical examination including the following investigations; serum bilirubin (total and direct) at admission and follow up, complete blood picture, reticulocyte count, coomb's test (direct), neonatal blood group \& RH, serum C- reactive protein (CRP), urine analysis and urine culture \& sensitivity.

\section{Urine culture \& sensitivity}

Urine was collected by the following methods: urine bag collection, urethral catheterization, suprapubic aspiration. The dye used for identification of organisms was gram stain. Organisms were either gram positive or gram negative. Media used were Blood Agar for gram positive bacteria, and Mac-cockney medium for gram negative bacteria. For further identification of gram negative bacteria, biochemical reaction was done. Nutrient Agar was used for sensitivity. For colony count the calibrated loop was used. Only colony counts $\geq 105$ were considered positive.

\section{Ethical points}

During the interview, the respondents of the neonates were simply informed about the aims of this study. Written consent was taken.

\section{Statistical analysis}

Analysis of data was done by IBM computer using SPSS (statistical program for social science version 12). Mann Whitney test used instead of unpaired t-test in non-parametric data $(\mathrm{SD}>50 \%$ 
mean). $\mathrm{P}$ value $>0.05$ insignificant, $\mathrm{P}<0.05$ significant, $\mathrm{P}<0.01$ highly significant. ${ }^{3}$

\section{Results}

The results of the present study showed that twenty five of one hundred neonates had positive urine culture.

Most of the subjects with UTI by urine analysis and culture $(66.1 \%$ and $80 \%$ respectively) were males, with no a statistically significant correlation between urine analysis result and gender. And also more than $50 \%$ of positive cases by culture were preterm with no a statistically significant correlation regarding gestational age.

Our current study showed that there was a statistically significant correlation between prolonged jaundice beyond 14 days and UTI either by urine analysis or culture. There is a statistically significant correlation between maternal infection and neonates with positive urine culture $(68 \%)$. The results of the present study showed that there is a strong correlation between UTI and unexplained jaundice. Such findings should raise an important question about the value of testing for a UTI as a part of the diagnostic evaluation of asymptomatic jaundiced infants.

Escherichia coli is the most common cause of UTI in neonates less than 8 weeks, ( $72 \%$ of our cases) followed by Klebsiella pneumonia infection (28\%). The current study showed no statistically significant difference regarding the presence or absence of urinary pus cells (by urine analysis and culture). As it is not evident in newborns with UTI. None of the neonates had significant microscopic hematuria (Figures 1-4), (Tables 1-4).

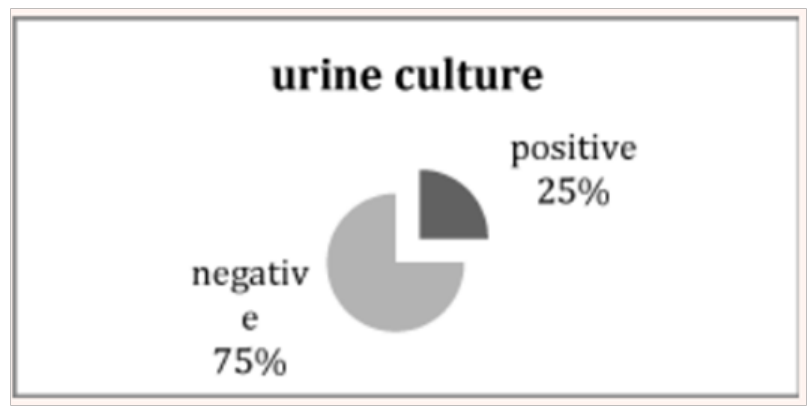

Figure I Distribution of urine culture result in cases of jaundiced neonates. It shows that $25 \%$ of cases had positive urine culture.

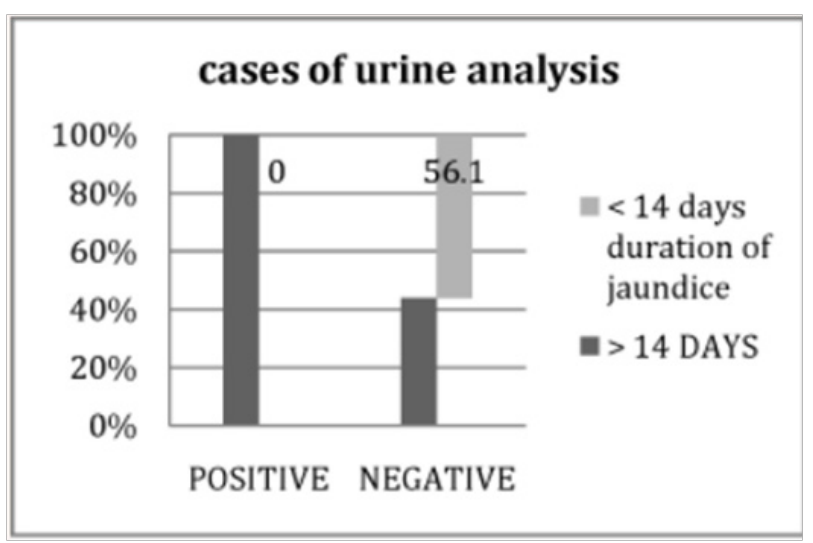

Figure 2 Association between positive and negative cases of urine analysis U/A regarding duration of jaundice.

It shows that $100 \%$ of positive cases of urine analysis, had prolonged duration of jaundice $>14$ days.

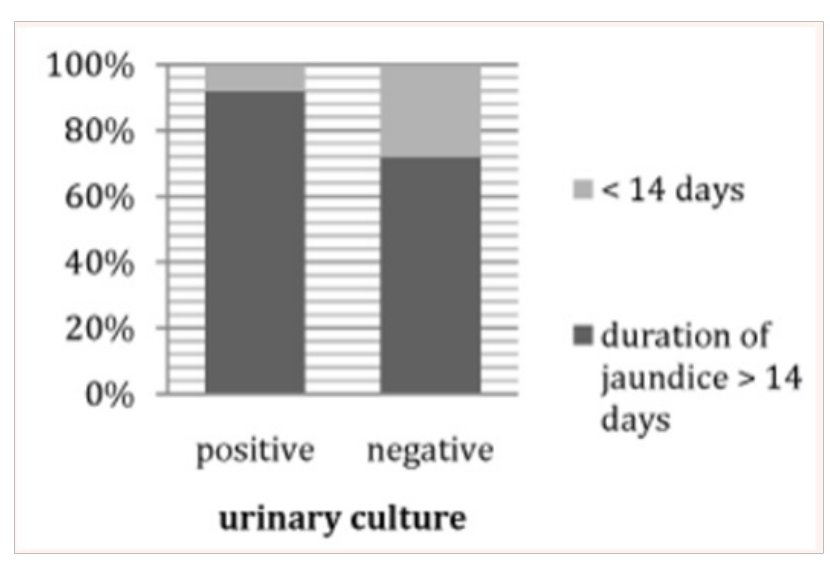

Figure 3 Association between positive and negative cases of urine culture $\mathrm{U} / \mathrm{C}$ regarding duration of jaundice.

It shows that $>90 \%$ of positive cases of urine culture had prolonged duration of jaundice $>$ |4days.

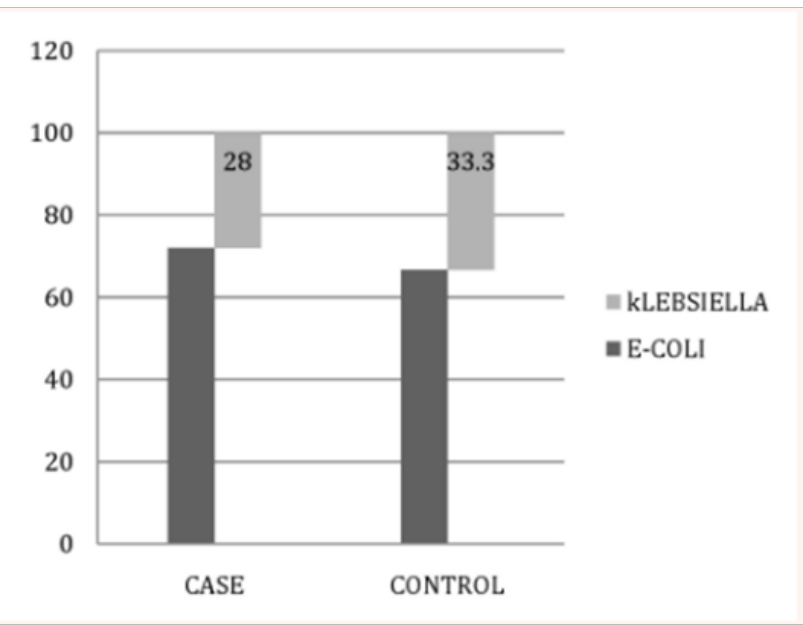

Figure 4 Association between culture organism types (E-coli \& Klebsiella) in case and control groups.

\section{Discussion}

The incidence of UTI is low in the first few days of life (2\%) even in neonates who are bacteremia, as a result urine cultures are not obtained for term infants who are being evaluated for early-onset sepsis before the first six days of life. ${ }^{4}$ In one large cohort study based on data from neonatal intensive care units, there was a $13 \%$ rate of a positive blood culture collected within three days of the urine culture with the same pathogenic organism. ${ }^{5}$ Bacteremia and sepsis have been well-documented as a cause of neonatal jaundice in seriously ill newborns and jaundice may be one of the first signs of bacterial sepsis in neonates in the first few days of life. ${ }^{2}$

Although there was no a statistically significant difference between case and control groups regarding urinary culture organism. We found that $25 \%$ of our cases had growth in their urine cultures, $72 \%$ of them had Escherichia coli infection, while $28 \%$ had Klebsiella pneumonia infection which agreed with the study by Wang et al. ${ }^{8}$ who reported that among 95 infants under 2 months of age diagnosed with UTI, the most common organism in urine culture was E-coli with no a statistically significant correlation. In another study by Biyikli et al. ${ }^{9}$ in Turkey, the high rate $(63 \%)$ of E-coli was reported among 
71 jaundiced infants who were diagnosed and treated for UTI. Garcia and Nager ${ }^{2}$ and Omar et al. ${ }^{10}$ reported other organisms, with lower frequencies, which are Enterobacter, Streptococcus viridans, Enterococcus, Streptococcus group B and Staphylococcus aureus.

We found that $52 \%$ of neonates with positive urine culture had pyuria, but without a statistically significant difference. On the other hand, the control group showed $100 \%$ of neonates with positive urine culture had pyuria without a statistically significant difference which agreed with the study by Wang et al. ${ }^{8}$ who reported no statistically significant difference between urinary culture and urinary pus cells. The difference in the incidence of UTI (by urine analysis) between the two groups (positive and negative) in our current study was slightly high. Through comparing our current study with the previous studies, we found that the incidence of UTI is higher in our cases as the overall prevalence of UTI was $59 \%$, which probably may be due to different sample sizes, different methods employed for evaluating patients, different socioeconomic status of societies, and perhaps due to specifications.

Table I Association between urinary culture and some clinical and demographic variables

\begin{tabular}{|c|c|c|c|c|c|c|}
\hline \multirow{3}{*}{ p -Value } & \multirow{3}{*}{$X^{2}$ test } & \multicolumn{2}{|c|}{ Urinary Culture } & \multirow{2}{*}{\multicolumn{2}{|c|}{ Negative $(\mathrm{N}=75)$}} & \multirow{3}{*}{ Variables } \\
\hline & & \multicolumn{2}{|c|}{ Positive $(\mathrm{N}=25)$} & & & \\
\hline & & No & $\%$ & No & $\%$ & \\
\hline$>0.05$ & 3.7 & $\begin{array}{l}20 \\
5\end{array}$ & $\begin{array}{l}80.0 \\
20.0\end{array}$ & $\begin{array}{l}44 \\
31\end{array}$ & $\begin{array}{l}58.7 \\
41.3\end{array}$ & $\begin{array}{l}\text { Gender } \\
\text { - Male } \\
\text { - Female }\end{array}$ \\
\hline$>0.05$ & 0.01 & $\begin{array}{l}12 \\
13\end{array}$ & $\begin{array}{l}48.0 \\
52.0\end{array}$ & $\begin{array}{l}35 \\
40\end{array}$ & $\begin{array}{l}46.7 \\
53.3\end{array}$ & $\begin{array}{l}\text { Mode of delivery } \\
\text { - Normal vaginal delivery } \\
\text { - Cesarean section }\end{array}$ \\
\hline$>0.05$ & 0.12 & $\begin{array}{l}11 \\
14\end{array}$ & $\begin{array}{l}44.0 \\
56.0\end{array}$ & $\begin{array}{l}36 \\
39\end{array}$ & $\begin{array}{l}48.0 \\
52.0\end{array}$ & $\begin{array}{l}\text { Gestational age } \\
-\geq 37 \text { weeks } \\
-<37 \text { weeks }\end{array}$ \\
\hline$>0.05$ & 0.51 & $\begin{array}{c}23 \\
2\end{array}$ & $\begin{array}{l}92.0 \\
8.0\end{array}$ & $\begin{array}{l}65 \\
10\end{array}$ & $\begin{array}{l}86.7 \\
13.3\end{array}$ & $\begin{array}{l}\text { Family history of jaundice in previous sibling } \\
\text { - Negative } \\
\text { - Positive }\end{array}$ \\
\hline$<0.05$ & 4.24 & $\begin{array}{l}23 \\
2\end{array}$ & $\begin{array}{l}92.0 \\
8.0\end{array}$ & $\begin{array}{l}54 \\
21\end{array}$ & $\begin{array}{l}72.0 \\
28.0\end{array}$ & $\begin{array}{l}\text { Duration of jaundice in the studied group } \\
-\geq 14 \text { days } \\
-<14 \text { days }\end{array}$ \\
\hline$>0.05$ & 2.28 & $\begin{array}{l}8 \\
17\end{array}$ & $\begin{array}{l}32.0 \\
68.0\end{array}$ & $\begin{array}{l}37 \\
38\end{array}$ & $\begin{array}{l}49.3 \\
50.7\end{array}$ & $\begin{array}{l}\text { Maternal Rh } \\
\text { - Negative } \\
\text { - Positive }\end{array}$ \\
\hline$>0.05$ & 5.99 & $\begin{array}{l}5 \\
4 \\
2 \\
14\end{array}$ & $\begin{array}{l}20.0 \\
16.0 \\
8.0 \\
56.0\end{array}$ & $\begin{array}{l}32 \\
12 \\
8 \\
23\end{array}$ & $\begin{array}{l}42.7 \\
16.0 \\
10.7 \\
30.7\end{array}$ & $\begin{array}{l}\text { Maternal ABO } \\
-A \\
-B \\
-A B \\
-O\end{array}$ \\
\hline$<0.05$ & 4.82 & $\begin{array}{l}8 \\
17\end{array}$ & $\begin{array}{l}32.0 \\
68.0\end{array}$ & $\begin{array}{l}43 \\
32\end{array}$ & $\begin{array}{l}57.3 \\
42.7\end{array}$ & $\begin{array}{l}\text { Maternal infection } \\
\text { - Negative } \\
\text { - Positive }\end{array}$ \\
\hline$>0.05$ & 0.05 & $\begin{array}{l}9 \\
8\end{array}$ & $\begin{array}{l}52.9 \\
47.1\end{array}$ & $\begin{array}{l}18 \\
14\end{array}$ & $\begin{array}{l}56.3 \\
43.7\end{array}$ & $\begin{array}{l}\text { Maternal infection type } \\
\text { - PROM } \\
\text { - UTI }\end{array}$ \\
\hline
\end{tabular}

This table shows that there is no statistical significant correlation between UTI by urine culture, and all previous variables except duration of jaundice and maternal infection.

Table 2 Association between case and control groups in relation to some Laboratory results

\begin{tabular}{|c|c|c|c|c|c|c|}
\hline \multirow{3}{*}{ p-Value } & \multirow{3}{*}{$X^{2}$ test } & \multicolumn{4}{|c|}{ UTI } & \multirow{3}{*}{ Variables } \\
\hline & & \multicolumn{2}{|c|}{ Controls $(\mathrm{N}=\mathbf{2 0})$} & \multicolumn{2}{|c|}{ Cases $(\mathrm{N}=100)$} & \\
\hline & & No & $\%$ & No & $\%$ & \\
\hline \multirow{3}{*}{$>0.05$} & \multirow{3}{*}{0.06} & & & & & Neonatal Rh \\
\hline & & 10 & 50.0 & 47 & 47.0 & - Negative \\
\hline & & 10 & 50.0 & 53 & 53.0 & - Positive \\
\hline \multirow{5}{*}{$<0.05$} & \multirow{5}{*}{9.07} & & & & & Neonatal $\mathrm{ABO}$ \\
\hline & & 7 & 35.0 & 41 & 41.0 & $-A$ \\
\hline & & 8 & 40.0 & 21 & 21.0 & $-B$ \\
\hline & & 4 & 20.0 & 8 & 8.0 & $-A B$ \\
\hline & & I & 5.0 & 30 & 30.0 & -0 \\
\hline \multirow{3}{*}{$>0.05$} & \multirow{3}{*}{0.49} & & & & & Coombs test \\
\hline & & 17 & 85.0 & 78 & 78.0 & - Negative \\
\hline & & 3 & 15.0 & 22 & 22.0 & - Positive \\
\hline \multirow{3}{*}{$>0.05$} & \multirow{3}{*}{0.25} & & & & & Urinary pus cells \\
\hline & & 13 & 65.0 & 59 & 59.0 & $-8-17$ cells \\
\hline & & 7 & 35.0 & 41 & 41.0 & $-I-5$ cells \\
\hline
\end{tabular}


Table Continued...

\begin{tabular}{|c|c|c|c|c|c|c|}
\hline \multirow{3}{*}{ p -Value } & \multirow{3}{*}{$\mathbf{X}^{2}$ test } & \multicolumn{4}{|c|}{ UTI } & \multirow{3}{*}{ Variables } \\
\hline & & \multicolumn{2}{|c|}{ Controls $(\mathrm{N}=\mathbf{2 0})$} & \multicolumn{2}{|c|}{ Cases $(\mathrm{N}=100)$} & \\
\hline & & No & $\%$ & No & $\%$ & \\
\hline$>0.05$ & 0.93 & $\begin{array}{c}17 \\
3\end{array}$ & $\begin{array}{l}85.0 \\
15.0\end{array}$ & $\begin{array}{l}75 \\
25\end{array}$ & $\begin{array}{l}75.0 \\
25.0\end{array}$ & $\begin{array}{l}\text { Urinary culture } \\
\text { - Negative } \\
\text { - Positive }\end{array}$ \\
\hline$>0.05$ & 0.04 & $\begin{array}{l}2 \\
1\end{array}$ & $\begin{array}{l}66.7 \\
33.3\end{array}$ & $\begin{array}{c}18 \\
7\end{array}$ & $\begin{array}{l}72.0 \\
28.0\end{array}$ & $\begin{array}{l}\text { Urinary culture organism } \\
\text { - E coli } \\
\text { - Kelebsiella }\end{array}$ \\
\hline
\end{tabular}

Table 3 Association between urinary culture and urinary pus cells in case and control groups

\begin{tabular}{|c|c|c|c|c|c|c|c|}
\hline \multirow{3}{*}{ p-Value } & \multirow{3}{*}{$X^{2}$ test } & \multicolumn{5}{|c|}{ Urinary Culture } & \multirow{3}{*}{ Groups } \\
\hline & & \multicolumn{2}{|c|}{ Positive } & \multicolumn{2}{|c|}{ Negative } & \multirow{2}{*}{ Variables } & \\
\hline & & No & $\%$ & No & $\%$ & & \\
\hline$>0.05$ & 0.68 & $\begin{array}{l}13 \\
12\end{array}$ & $\begin{array}{l}52.0 \\
48.0\end{array}$ & $\begin{array}{c}46 \\
29\end{array}$ & $\begin{array}{l}61.3 \\
29.0\end{array}$ & $\begin{array}{l}\text { Urinary pus cells } \\
-8-17 \\
-1-5\end{array}$ & Cases \\
\hline$>0.05$ & 1.9 & $\begin{array}{l}3 \\
0\end{array}$ & $\begin{array}{l}100.0 \\
0.0\end{array}$ & $\begin{array}{l}10 \\
7\end{array}$ & $\begin{array}{l}58.8 \\
41.2\end{array}$ & $\begin{array}{l}\text { Urinary pus cells } \\
-8-17 \\
-1-5\end{array}$ & Controls \\
\hline
\end{tabular}

Table 4 Association between cases and control groups in relation to different laboratory results

\begin{tabular}{|c|c|c|c|c|}
\hline Variables & Groups & Mean \pm SD & t- test & p- value \\
\hline \multirow{2}{*}{ TSB mg/dl } & Cases & $14.92 \pm 2.54$ & \multirow{2}{*}{$55.04 * *$} & \multirow{2}{*}{$<0.01$} \\
\hline & Controls & $0.94 \pm 0.05$ & & \\
\hline \multirow{2}{*}{ DSB mg/dl } & Cases & $0.65 \pm 0.22$ & \multirow{2}{*}{$7.2^{*}$} & \multirow{2}{*}{$<0.01$} \\
\hline & Controls & $0.13 \pm 0.09$ & & \\
\hline \multirow{2}{*}{ RTCs \% } & Cases & $2.34 \pm 1.18$ & \multirow{2}{*}{$3.73 *$} & \multirow{2}{*}{$<0.01$} \\
\hline & Controls & $3.77 \pm 1.64$ & & \\
\hline \multirow{2}{*}{ CRP mg/l } & Cases & $0.40 \pm 0.49$ & \multirow{2}{*}{$3.26 *$} & \multirow{2}{*}{$<0.01$} \\
\hline & Controls & $0.80 \pm 0.4 \mathrm{I}$ & & \\
\hline \multirow{2}{*}{ Hemoglobin $(\mathrm{gm} / \mathrm{dl})$} & Cases & $|4.28 \pm 0.5|$ & \multirow{2}{*}{2.03} & \multirow{2}{*}{$>0.05$} \\
\hline & Controls & $13.44 \pm 1.83$ & & \\
\hline \multirow{2}{*}{ HCT \% } & Cases & $42.71 \pm 5.87$ & \multirow{2}{*}{3.08} & \multirow{2}{*}{$<0.01$} \\
\hline & Controls & $36.09 \pm 9.25$ & & \\
\hline \multirow{2}{*}{ Platelets (/cumm) } & Cases & $300.53 \pm 96.35$ & \multirow{2}{*}{0.69} & \multirow{2}{*}{$>0.05$} \\
\hline & Controls & $284.65 \pm 81.64$ & & \\
\hline \multirow{2}{*}{ WBCs(/cumm) } & Cases & $8.60 \pm 1.99$ & \multirow{2}{*}{3.58} & \multirow{2}{*}{$<0.01$} \\
\hline & Controls & $|2.4| \pm 4.67$ & & \\
\hline \multirow{2}{*}{ Neutrophils \% } & Cases & $31.12 \pm 10.63$ & \multirow{2}{*}{$0.52 *$} & \multirow{2}{*}{$>0.05$} \\
\hline & Controls & $35.18 \pm 14.88$ & & \\
\hline \multirow{2}{*}{ Monocytes \% } & Cases & $8.48 \pm 3.11$ & \multirow{2}{*}{$3.47^{*}$} & \multirow{2}{*}{$<0.01$} \\
\hline & Controls & $5.68 \pm 2.61$ & & \\
\hline \multirow{2}{*}{ Lymphocytes \% } & Cases & $51.22 \pm 4.90$ & \multirow{2}{*}{ I.7I } & \multirow{2}{*}{$>0.05$} \\
\hline & Controls & $56.80 \pm 14.44$ & & \\
\hline Fsinombils \% & Cases & $2.97 \pm 0.79$ & $326 *$ & < > > > > > \\
\hline EsInopilis \% & Controls & $1.83 \pm 2.09$ & $3.20^{\circ}$ & -0.01 \\
\hline Roconhils \% & Cases & $0.89 \pm 0.36$ & $320 *$ & > > > > > > \\
\hline Dasopinis \% & Controls & $0.53 \pm 0.49$ & 3.27 & -0.01 \\
\hline
\end{tabular}

UTI (by urine analysis) was more common among boys in our current study (66.1\%), but without significant correlation regarding gender, which agreed with Ghaemi et al. ${ }^{11}$ who reported that UTI was more common in boys with no significant correlation. Based on the pediatric texts, most of the UTIs in boys occur in the first year of life, during which the percentage of UTI in boys is 2.8 times more than in girls. While after this period, the percentage in girls is 10 times more than in boys. In our current study the percentage of boys 20 males and only 5 females among the positive UTI group with no a statistically significant difference between positive and negative UTI groups (p-value $>0.05$.).
Furthermore in the studies by Lee et al..$^{12}$ and Chang et al. ${ }^{13}$ showed a male predominance. Ghaemi et al. ${ }^{11}$ found that nearly $60 \%$ of male infants with UTI were uncircumcised and Singh-Grewal et al. ${ }^{14}$ found that circumcision was associated with a significantly reduced risk of UTI. We found there is a significant correlation between the duration of jaundice ( $\geq 14$ days) from one side and positive urine culture and maternal infection history ( $\mathrm{p}$-value $<0.05$ ) from the other side. This findings are in agreement with Chin et al. ${ }^{6}$ who found that urinary tract infections (UTI) are attributed as one of the main reasons for prolonged jaundice.

A number of possible mechanisms for UTI-caused jaundice have been documented, including: hemolysis, direct invasion of the 
liver parenchyma by blood-borne or lymph borne micro-organisms, hepatocellular injury by circulating endotoxins, and non-specific injury to the liver related to hyperpyrexia, malnutrition and toxemia. Jaundice can lead to UTI by altering bactericidal activity in the sera of jaundiced newborns making them more prone to infections as that reported in the study by Cisowska et al. ${ }^{15}$

Some cases of hemolysis (a diagnosis based on the presence of anemia and elevated reticulocyte counts) have been reported to contribute to jaundice in patients with infections caused by E-coli, Enterobacter aerogenes and Enterococcus. Certain strains of E-coli produce a hemolysis demonstrated by a high titer of anti- $\alpha$ hemolytic antibodies in a patient's serum and by hemolytic zones on a blood agar plate. Increased red cell fragility in E- coli sepsis is also reported to be a common factor of haemolysis. However, haemolysis is not thought to be the major cause of UTI-related jaundice, although even mild haemolysis can overload the immature liver conjugating mechanism, leading to an increase in serum bilirubin levels. Direct bacterial invasion of the liver parenchyma leading to toxic hepatitis and jaundice might explain some cases of UTI related prolonged jaundice.

In a retrospective study performed by Singh-Grewal et al. ${ }^{13}$ reported that infection with E-coli had a stronger association with conjugated than unconjugated hyperbilirubinemia. Such association was not found with Klebsiella pneumonia infection. Our results did not demonstrate such a correlation. Pro inflammatory cytokines can either reduce transporter gene expression or directly inhibit transport protein function. ${ }^{16}$

\section{Conclusion}

Finally we conclude that

i. Maternal (obstetric) infections should be properly investigated and treated to prevent UTI in newborns and its squealae (jaundice).

ii. Testing for UTI should be a part of the diagnostic evaluation of neonates with prolonged unexplained jaundice. It is necessary to do a urine culture in those infants as urine analysis is not a sensitive test for UTI and has many false negative results which lead to misdiagnosis of UTI.

iii. Investigating UTI as a cause of hyperbilirubinemia especially in cases of prolonged jaundice more than 14 days. iv. Further studies are needed to clarify the effect of hyperbilirubinemia on the bactericidal activity in the sera of jaundiced infants, and whether UTI is the cause of hyperbilirubinemia or hyper -bilirubinemia is the cause of UTI as a result of a functional defect in the complement system.

\section{Acknowledgments}

None.

\section{Conflicts of Interest}

There is no conflict of interest.

\section{Funding}

None.

\section{References}

1. Bilgen $\mathrm{H}$, Ozek $\mathrm{E}$, Unver $\mathrm{T}$, et al. Urinary tract infection and hyperbilirubinemia. The Turkish Journal of Pediatrics. 2006;48:51-55.

2. Garcia FJ, Nager AL. Jaundice as an Early Diagnostic Sign of Urinary Tract Infection in Infancy. Pediatrics. 2002;109(5):846-851.

3. Knapp ML, Miller GR. Handbook of interpersonal communication. 2nd edn. Beverly Hills Sage, California, USA, 1994. p. 45.

4. Riskin A, Toropine A, Bader D, et al. Is it justified to include urine cultures in early ( $<72$ hours) neonatal sepsis evaluations of term and late preterm infants? Am J Perinatol. 2013;30(6):499-504.

5. Downey LC, Benjamin DK Jr, Clark RH, et al. Urinary tract infection concordance with positive blood and cerebrospinal fluid cultures in the neonatal intensive care unit. J Perinatol. 2013;33(4):302-306.

6. Chin HT, Jeng MJ, Soong WJ, et al. Hyperbilirubinemia with urinary tract infection in infants younger than eight weeks old. J Chin Med Assoc. 2011;74(4):159-163.

7. Lin CW, Chiou YH, Chen YY, et al. Urinary Tract Infection in Neonates. Clinical Neonatology. 1999;6(2):1-4.

8. Wang SF, Huang FY, Chiu NC, et al. Urinary tract infection in infants less than 2 months of age. Zhonghua Min Guo Xiao Er Ke Yi Xue Hui Za Zhi. 1994;35(4):294-300.

9. Biyikli NK, Alpay H, Ozek E, et al. Neonatal urinary tract infections: Analysis of the patients and recurrences. Pediatr Int. 2004;46(1):21-25.

10. Omar C, Hamza S, Bassem AM, et al. Urinary tract infection and indirect hyperbilirubinemia in newborns. N Am J Med Sci. 2011;3(12):544-547.

11. Ghaemi S, Fesharaki RJ, Kelishadi R. Late onset jaundice and urinary tract infection in neonates. Indian J Pediatr. 2007;74(2): 139-141.

12. Lee HC, Fang SB, Yeung CY, et al. Urinary tract infections in infants: comparison between those with conjugated vs unconjugated hyperbilirubinaemia. Ann Trop Paediatr. 2005;25(4):277-282.

13. Chang SL, Shortliffe LD. Pediatric urinary tract infections. Pediatric Clinics of North America. 2006;53(3):379-400.

14. Singh-Grewal D, Macdessi J, Craig J. Circumcision for the prevention of urinary tract infection in boys: a systematic review of randomised trials and observational studies. Arch Dis Child. 2005;90(8):853-858.

15. Cisowska A, Dorota T, Ek Goska I, et al. The bactericidal activity of complement in sera of children with infectious hyperbilirubinemia. $A d v$ Clin Exp Med. 2007;16(5):629-634.

16. Wagner M, Zollner G, Trauner M. New molecular insights into the mechanisms of cholestasis. J Hepatol. 2009;51(3):565-580. 